\title{
ARE WOMEN REALLY PAID MORE THAN MEN IN KOSOVO? UNPICKING THE EVIDENCE
}

Ardiana Gashi, Nick Adnett

\section{Abstract}

A recent survey found that the unadjusted average hourly net wage rate of female employees in Kosovo exceeded that of male employees. This reverse gender wage gap makes Kosovo a curiosity, though results from other countries suggest that there is an inverse relationship between the size of the gender pay gap in a country and its female labour force participation rate. In the analysis below we estimate earning functions for female and male employees in Kosovo. Using decomposition analyses we then examine the size of the explained and unexplained gender wage gaps. A novel feature of the investigation is that we incorporate into the analysis gender differences in the allocation of time. We find that the superior productivity-related characteristics of female employees in Kosovo hides the magnitude of the difficulties they still face in the labour market. Hence, we conclude that once we focus on workers with similar observed productivity-related characteristics, women in Kosovo are paid significantly less than men.

JEL codes: J16, J24, J31, J71, I26

\section{INTRODUCTION}

In labour markets across the world recent decades have been characterised by falling gender gaps (Stotsky et al. 2016; World Economic Forum 2019). However, despite the closing of gender gaps in educational attainment and the increased attachment of women to the labour market, a significant gender wage gap persists in most countries and regions (Kunze 2018). Comparison of the median earnings of full-time employees and the self-employed in OECD countries indicates an average gender wage gap of around 13\% in 2018 (OECD 2020). This represents a mere $1 \%$ improvement in women's relative earnings over the previous decade. Within the OECD the gender earnings gap ranges from just under $4 \%$ in Belgium to $34 \%$ in Korea. According to the World Economic Forum (2019) whilst there has been a slight improvement in women's relative earnings in OECD countries, their position on average has worsened in non-OECD countries in recent years. The non-random
Ardiana Gashi, $\mathrm{PhD}$

(corresponding author)

Associate Professor

Faculty of Economics

University of Prishtina

Street Agim Ramadani, n.n. 10000 Prishtina, Kosovo

E-mail: Ardiana.Gashi@uni-pr.edu

Nick Adnett, $\mathrm{PhD}$

Professor

Business School

Staffordshire University, UK

Email: N.J.Adnett@staffs.ac.uk 
selection of women into work means that countries with low female labour force participation (FLFP) generally have relatively low gender wage gaps. This is the consequence of females with high potential labour market earnings being more likely to be economically active than those with lower potential earnings. Hence, comparing the wages of 'average' female employees with those of 'average' male employees (the unadjusted wage gap) is likely to be a poor indicator of the wage gap between female and male employees with comparable observed productivity-related characteristics (the adjusted wage gap). Many of the previously transitioning countries of Central and Eastern Europe typically had large gender wage gaps but also low female employment rates, though the latter have generally increased since 2010 (Kunze 2018). In these countries a relatively small proportion of the gender wage gap could be explained by the different characteristics of female and male employees (Redmond and McGuinness 2017; Khitarishvili 2019).

A stark gender divide in the labour market persists in Kosovo. According to the Labour Force Survey, in 2019 , only $21.1 \%$ of women were economically active as opposed to $59.7 \%$ of men (KAS 2020). Although they have a much lower activity rate, the unemployment rate of women remains higher than that of men. Whilst women represent $49.8 \%$ of the working age population, they constitute only $22.9 \%$ of the total employed individuals in Kosovo (KAS 2020). This is due to women's low employment rate, recorded at $13.9 \%$ in 2018 as opposed to $46.2 \%$ for men - a rate more than three times higher than that of women. Between 2012 and 2019 the average gender gap in employment was about 31 percentage points. Gashi et al. (2019) find that both demand and supply factors account for the low FLFP in Kosovo. Their results confirm that age, marital status, educational attainment, local labour market demand and the composition of the household are significant determinants of FLFP.

Given its very low FLFP it is not too surprising that successive Kosovo Labour Force Surveys indicated the absence of a gender wage gap or that a recent survey found that the average hourly wage rates of female employees exceeded that of men. However, given the different characteristics of male and female employees in Kosovo, even a negative unadjusted gender gap may be consistent with a large positive adjusted gap. A motivation for this study is that there has been no investigation of this possibility or indeed any previous systematic analysis of the size and causes of the adult gender wage gap in Kosovo. A further novel feature of this study is the inclusion of an analysis of the contribution to gender wage inequality of differences in the allocation of time.
The analysis is organised as follows. The following section presents a literature review on the causes of the gender pay gap, followed in the third section by an introduction to the data and an explanation of the methodology utilised in this investigation. The fourth section discusses the determinants of the gender wage gap in Kosovo and the decomposition of the gap into 'explained' and 'unexplained' components. In this section we also introduce consideration of the impact of gender differences in the allocation of time. The final section brings together the findings of our investigation and draws conclusions about the causes of the current puzzling unadjusted gender wage gap in Kosovo.

\section{WHAT DO WE KNOW ABOUT THE DETERMINANTS OF THE GENDER WAGE GAP?}

To investigate the causes of the gender wage gap it is necessary to decompose the gap into that part which can be explained by differences in characteristics which influence labour market performance and rewards and that which cannot be explained by these differences (the unexplained part). The "unexplained" part is often used as a measure for discrimination, resulting from employers' preferences, social norms or statistical discrimination, but it also subsumes the effects of group differences in unobserved predictors (Kunze 2018). The unexplained differences could be due to personal characteristics which affect a worker's productivity and job choice but cannot be observed or adequately measured, such as attitudes towards risk-taking, preferences regarding the non-pecuniary aspects of an employment, bargaining ability, etc., which have been systematically observed to differ between men and women. In addition, the unexplained differences in wages could be due to discriminatory treatment of women in the labour market, which is reflected in the different returns for men and women to labour market characteristics such as education and experience.

Blau and Khan (2016) for the US, Arulampalam et al. (2007) for the EU and Weichselbaumer and WinterEbmer (2005) for the OECD have found that differences in educational attainment and labour market experience can explain a large part of the unadjusted gender pay gap. Further explanation is generated if productivity and reward-related characteristics such as tenure, occupation, industry and union membership are included. Yet more explanation is added if demographic factors, such as marital status, the presence of children and aged dependents in the household are added. The degree of industrial and occupational 
segregation in the labour market has also been found to be a significant determinant of the wage gap in a number of countries (Khitarishvili et al. 2018). Overall, Leythienne and Ronkowski (2018) find that just under a third of the $17 \%$ gender gap in hourly earnings in the EU could be explained with such an augmented specification. Avlijaš et al. (2013) report that the unadjusted gender pay gaps were generally smaller in the Western Balkans than in the EU-27 with a gap of just $12 \%$ in Serbia. They find that given the, on average, superior productivity-related characteristics of female employees in this region, the adjusted gender pay gaps are higher, ranging from $20 \%$ in Serbia to $22.7 \%$ in Macedonia.

Blau and Kahn (2016) found that whilst human capital factors explained $27 \%$ of the gender earnings gap in 1980, they only explained 5\% of the gap in 2010 . Over the same period the percentage of the gap explained by occupation and industry choices rose from $27 \%$ to $49 \%$. Similarly, Redmond and McGuinness (2017) point out that over time as the unadjusted gender wage gap has gradually declined in Europe, the unexplained portion of the gap has tended to rise. The degree of convergence of wage-determining characteristics by gender differs between countries, with the result that whilst differences in characteristics are important determinants of the gender wage gap in some Central and peripheral European countries, they contribute little in most Eastern European economies. However, Redmond and McGuinness do find that gender differences in job preferences are significant contributors to the gender wage gap, with females preferring jobs closer to home and with greater job security, whilst males are more motivated by financial gain. Similarly, Chowdbury et al. (2018) find that occupational and industry sorting is a significant determinant of the gender wage gap in Vietnam. They too find some evidence that women have a greater preference for some non-monetary job characteristics, such as formal contracts, social and health insurance, paid leave and fewer weekly working hours. Petrongolo and Ronchi (2020) argue that women's greater caring responsibilities in the household are in part related to gender identity norms and societal attitudes to gender roles. In turn this causes women to have a greater distaste for commuting than men and, as a consequence, women are more likely to trade-off the possibility of finding higher wage offers for shorter commutes. Women's prevalent role in family responsibilities may also lead to a preference for shorter working hours and hence would suggest that the gender pay gap in terms of monthly earnings would be greater than that for hourly wages.

There has been no previous study of the gender wage gap amongst adults in Kosovo, though Pastore et al. (2013) did analyse the gender earnings gap experienced by early career employees. They found that young women's lower overall level of educational attainment was masked by the self-selection of the more educated females into employment. Their decomposition analysis found that gender differences in earnings were wholly explained by differences in characteristics rather than returns to those characteristics. Of particular relevance to Kosovo are studies which cover countries with large informal labour markets. Yahmed (2016) finds that in Brazil the unadjusted gender wage gap is two and half times greater in the informal sector than in the formal one. However, that study finds that in the informal sector differences in returns to productivity-related characteristics is not a significant determinant of the gender wage gap. Salman et al. (2019) study the gender wage gap in two economies with similar FLFP rates to those of Kosovo: Egypt and Jordan. They find very large unadjusted gender wage gaps, nearly $40 \%$ in Jordan, and differences in remuneration by gender which cannot be explained by differences in productivity-related characteristics.

The lower incidence of promotion among female employees and the glass ceilings they often encounter have been found to be significant contributors to gender wage gaps in developed economies. Several studies have attributed these phenomena to gender differences in working hours (for example Cha and Weeden 2014 and Frederisen and Kato 2018). Goldin (2014) has shown that in the US the occupations characterised by the greatest returns to working long hours are those with greatest gender pay gaps. Across the EU, Leythienne and Ronkowski (2018) report that in 2014 women were paid for 14 hours a month fewer than males, though this gap was much smaller in the former transition member states. Weeden et al. (2016) find large differences between gender and parental status groups in the incidence of working long hours in the US. The sharply rising premia paid to those working longer hours was found to contribute substantially to the gender earnings gap and the motherhood penalty.

The motherhood penalty, where mothers earn less than women without children, is well-established and documented (Adda et al. 2017; Kleven et al. 2019)). Explanations for this penalty have been drawn from human capital theory, the theory of compensating wage differentials, the theory of work-effort and the selection of women into motherhood. Using metaanalysis, Cukrowska-Torzewska and Matysiak (2018) found an average motherhood wage gap of around 3.7 percent. They concluded that the wage gaps associated with having multiple children were mostly 
explained by the loss of mothers' human capital during child-related career breaks, whilst the gaps associated with one child were predominantly driven by the mothers' choice of jobs and occupations that pay less. Using data from the USA, Juhn and McCue (2016) concluded that the motherhood gap remains substantial, even among their most recent birth cohort. Compared to married women without children, married women with pre-school age children had approximately 35 percent lower earnings, while married women with school-aged children had approximately 15 percent lower earnings.

This literature review provides the basis for the specification of the empirical model presented in the next section.

\section{DATA, METHODOLOGY AND THE UNADJUSTED GENDER PAY GAP}

To assess the size and determinants of the gender pay gap in Kosovo data are extracted from the Labour Force and Time Use Survey conducted in 2017 and commissioned by the Millennium Challenge Corporation (MCC) in Kosovo. The survey was conducted with 8,533 households, collecting employment information on 32,742 individuals and the completion of 8,604 extended interviews. The survey was crosssectional, with data collection occurring over a 17week period. Similar to the Labour Force Survey (LFS) conducted by the Kosovo Agency of Statistics (KAS), the MCC survey is aligned with Eurostat methodology.

The rationale for using the MCC survey is that it collected data on actual wages, whilst in the LFS respondents are provided with list of wage intervals. The 2018 LFS indicates very little difference between the genders in the distribution of monthly earnings (KAS, 2019). In the analysis below the unadjusted and adjusted pay gaps are estimated, for individuals that hold the status of employee, i.e. excluding the selfemployed. From the survey, in total there were 8,367 waged employees, out of which $32 \%(2,663)$ were women. While the questionnaire asked about the net monthly wages in the main job, for the purpose of this analysis, using the calculator from the Kosovo Tax Administration, the monthly net wage was converted into the gross hourly wage. The survey data indicates that the average gross monthly wage of women was 350 Eur whilst men earned 384 Eur. Calculated by hours of work, women earned 0.15 Eur more per hour than men, namely women earned 2.48 Eur per hour and men 2.33 Eur per hour. Results from the Mincer equation ${ }^{1}$ with gender as the only regressor estimates the unadjusted gender gap at $10.7 \%$ using log of monthly wages, higher than the gap in Albania recorded at $10.5 \%$ (Institute of Statistics of Republic of Albania 2018) in 2017. When using log of gross hourly earnings, women are found to be paid more than men, with the unadjusted gap estimated at $6.5 \%$. The major cause of this large difference between the estimated gender wage gaps for hourly and monthly wages is differences in working hours. The average working hours per month for women was 163 hours, 29 hours fewer than those of men; i.e. men worked on average $18 \%$ more hours per month. Considering only fulltime employees, working women on average worked 169 hours per month and men worked 195 hours per month. These differences are approximately twice the size of those reported by Leythienne and Ronkowski (2018) for the former transition EU member states. As discussed above, this difference in working hours may reflect difference in innate preferences between women and men and/or a response to differences in their household's allocation of home production and/or employers' discriminatory allocation of working hour across their employees.

Table 1 provides information on the characteristics of the employees surveyed and their jobs together with the unadjusted gender pay gaps, using data for monthly wages and hourly wages. Focusing on the level of completed education the largest unadjusted gap using monthly wages exists between women and men with the lowest and highest levels of education: it is $25 \%$ among those with less than primary education and $19 \%$ among employees with tertiary post-graduate education. The latter finding is also observed for the gap in hourly wages: the gap between women and men with completed higher education is estimated to be $22 \%$. Female employee's overall higher hourly average wage rate was due to their, on average, superior level of educational attainment. For example, $41 \%$ of women employees had completed higher education compared to only $19 \%$ of male employees.

Women were paid less than men across all types of employers. The largest unadjusted gap is observed in private sector employees, $21 \%$ when using monthly wages and $7 \%$ when using hourly wages. Larger shares of women were employed in the, on average, higher-paying public sector which also contributed to their overall higher hourly wage rates. The unadjusted gender monthly wage gap was particularly high amongst those in part-time employment (24.6\%) compared to $8.4 \%$ for full-time work. However, parttime women were paid more per hour and thus the large gap in monthly wages was in a large part due to men working approximately $50 \%$ longer hours. Note that whilst employment regulations in Kosovo specify premium rates for overtime working, in practice these 
Table 1. Distribution of Employees and Unadjusted Gender Gap

\begin{tabular}{|c|c|c|c|c|c|c|c|c|}
\hline & \multicolumn{2}{|c|}{$\begin{array}{l}\text { Distribution of } \\
\text { employees }\end{array}$} & \multicolumn{3}{|c|}{ Gross average hourly wage } & \multicolumn{3}{|c|}{$\begin{array}{l}\text { Gross average monthly } \\
\text { wage }\end{array}$} \\
\hline Waged employees & $\begin{array}{c}\% \text { of all } \\
\text { women } \\
\text { em- } \\
\text { ployed }\end{array}$ & $\begin{array}{c}\text { \% all } \\
\text { men } \\
\text { em- } \\
\text { ployed }\end{array}$ & W & M & $\begin{array}{c}\text { Wage } \\
\text { gap in } \\
\%\end{array}$ & W & M & $\begin{array}{c}\text { Wage } \\
\text { gap in } \\
\%\end{array}$ \\
\hline \multicolumn{9}{|l|}{ Education level } \\
\hline $\begin{array}{l}\text { No education or primary or lower-sec- } \\
\text { ondary completed-(ISCED } 0+1+2 \text { ) }\end{array}$ & $12 \%$ & $18 \%$ & 1.53 & 1.57 & $3 \%$ & 233 & 309 & $25 \%$ \\
\hline Secondary education-(ISCED 3+4) & $48 \%$ & $63 \%$ & 1.86 & 2.08 & $11 \%$ & 298 & 361 & $17 \%$ \\
\hline Tertiary graduate degree-(ISCED 5+6) & $33 \%$ & $15 \%$ & 3.38 & 3.42 & $1 \%$ & 430 & 504 & $15 \%$ \\
\hline Tertiary post-graduate-(ISCED 7+8) & $8 \%$ & $4 \%$ & 4.2 & 5.4 & $22 \%$ & 533 & 661 & $19 \%$ \\
\hline Number of observations & 1,657 & 4,698 & & & & & & \\
\hline \multicolumn{9}{|l|}{ Sector of employment } \\
\hline Private & $53 \%$ & $68 \%$ & 1.67 & 1.79 & $7 \%$ & 266 & 335 & $21 \%$ \\
\hline Public & $44 \%$ & $30 \%$ & 3.41 & 3.48 & $2 \%$ & 446 & 485 & $8 \%$ \\
\hline NGO or international organisations & $3 \%$ & $2 \%$ & 2.48 & 2.93 & $15 \%$ & 354 & 460 & $23 \%$ \\
\hline Full time & $91 \%$ & $91 \%$ & 2.44 & 2.31 & $-6 \%$ & 362 & 395 & $8 \%$ \\
\hline Part time & $9 \%$ & $10 \%$ & 2.56 & 2.44 & $-5 \%$ & 196 & 260 & $25 \%$ \\
\hline Formal employment & $76 \%$ & $60 \%$ & 2.76 & 2.84 & $3 \%$ & 391 & 439 & $11 \%$ \\
\hline Informal employment & $24 \%$ & $40 \%$ & 1.58 & 1.52 & $-4 \%$ & 212 & 295 & $28 \%$ \\
\hline Number of observations & 1,657 & 4,698 & & & & & & \\
\hline \multicolumn{9}{|l|}{ Occupations } \\
\hline Managers & $4 \%$ & $5 \%$ & 3.03 & 3.07 & $1 \%$ & 478 & 554 & $14 \%$ \\
\hline Professionals & $34 \%$ & $14 \%$ & 2.85 & 4.3 & $34 \%$ & 406 & 675 & $40 \%$ \\
\hline Services and Sales Workers & $19 \%$ & $14 \%$ & 1.38 & 1.54 & $10 \%$ & 239 & 292 & $18 \%$ \\
\hline Craft and Related Trades Workers & $5 \%$ & $14 \%$ & 1.09 & 2.04 & $47 \%$ & 203 & 369 & $45 \%$ \\
\hline Elementary Occupations & $12 \%$ & $24 \%$ & 2.06 & 1.74 & $-18 \%$ & 260 & 331 & $21 \%$ \\
\hline Other & $26 \%$ & $29 \%$ & 2.11 & 2.41 & $12 \%$ & 353 & 387 & $9 \%$ \\
\hline Number of observations & 1,657 & 4,698 & & & & & & \\
\hline \multicolumn{9}{|l|}{ Economic sectors } \\
\hline Manufacturing & $6 \%$ & $8 \%$ & 1.51 & 1.7 & $11 \%$ & 263 & 335 & $21 \%$ \\
\hline Construction ${ }^{2}$ & $1 \%$ & $19 \%$ & 3.03 & 1.88 & $-61 \%$ & 413 & 372 & $-11 \%$ \\
\hline $\begin{array}{l}\text { Wholesale and retail trade; repair of } \\
\text { motor vehicles and motorcycles }\end{array}$ & $14 \%$ & $8 \%$ & 1.42 & 1.7 & $16 \%$ & 239 & 324 & $26 \%$ \\
\hline Public administration and defence & $4 \%$ & $9 \%$ & 2.58 & 2.88 & $10 \%$ & 408 & 452 & $10 \%$ \\
\hline Education & $22 \%$ & $9 \%$ & 3.92 & 4.06 & $3 \%$ & 448 & 468 & $4 \%$ \\
\hline Health and social work activities & $15 \%$ & $3 \%$ & 2.62 & 2.76 & $5 \%$ & 414 & 463 & $11 \%$ \\
\hline Other service activities & $17 \%$ & $14 \%$ & 1.89 & 1.83 & $-3 \%$ & 273 & 323 & $15 \%$ \\
\hline Other activities & $24 \%$ & $30 \%$ & 2.11 & 2.41 & $12 \%$ & 332 & 395 & $16 \%$ \\
\hline Number of observations & 1,657 & 4,698 & & & & & & \\
\hline
\end{tabular}

Source: MCC LFTUS 2017, authors' calculations 
are rarely paid (Kosovo Democratic Institute 2017; Riinvest Institute 2017). The gender gross monthly wage gap was higher in informal jobs (28.1\%) compared to formal jobs (10.9\%). A finding similar to that of Yahmed (2016) for Brazil. However, with regards to the hourly wage, the unadjusted gender pay gap was negative for informal employees (-3.9\%). There is some evidence of occupational and industrial segregation in Kosovo. With males disproportionately employed in craft and elementary occupations and in the construction sector with females being more likely to be employed in professional occupations and the education and health sectors. With the exception of the hourly rate of elementary occupations, women were paid less than men in all occupations. The widest gap is found within craft and related trade workers and professionals, with unadjusted gap in monthly wages as large as $45 \%$ and $47 \%$ for the former group, using monthly wages and hourly wages respectively, and $40 \%$ and $34 \%$ for professionals. It is important to note that this latter occupational group accounted for $34 \%$ of all female employees. As noted above, only in elementary occupations were women paid more by the hour, with a very large female premium of $18 \%$. This occupation accounted for $12 \%$ of women employees and $24 \%$ of male ones. The largest gender pay gaps were in the wholesale and retail trade sector, whilst the smallest gap was found in the education, public administration and health sectors, which together accounted for $41 \%$ of all female employees.

The next sub-section discusses findings on the adjusted gender pay gap in Kosovo.

\subsection{Model specification}

In line with the dominant approach in the literature, our dependent variable in the Mincer earnings function is the gross hourly wage, but we briefly comment on the results for the gross monthly wage where there is a difference. Building from Mincer's original specification that was linear with respect to education and quadratic with respect to the proxy for work experience (age), the findings from previous studies suggest that three main groups of explanatory variables be included: personal and household, job and employer characteristics.

\section{Personal and household characteristics}

The specification includes a dummy variable for marital status, taking a value of 1 for married individuals and zero otherwise. The empirical specification allows for a non-linear relationship between age and earnings with age and age square being included.

To examine the impact of the level of completed education on wages, three dummy variables are included: a Group 2 dummy variable with value of 1 if a person's highest completed education was secondary or post-secondary vocational education and zero otherwise; Group 3 is set to 1 for persons whose highest educational attainment was a completed graduate tertiary degree, zero otherwise; and Group 4 represents individuals that have completed a post-graduate tertiary degree. The benchmark category is those who have not completed any schooling or whose highest completed education was primary or lower secondary.

To test for the motherhood penalty the model also includes a dummy indicating if the household has children under the age of 15 (the latter is used since the household dataset does not attach mothers to their children). Identification of whether a household contains any elderly members (aged 65 or older) enables an assessment of the impact of the availability of informal childcare within the household, which may positively affect women's wages through a greater willingness to undertake more working and/or commuting time. This effect may be particularly important in the context of Kosovo where it is not uncommon for more than two generations of family members to live in the same household (e.g. based on KAS 2012 data, it is estimated that around one in three households consists of more than one nuclear family). However, the presence of elderly family members may also generate a higher demand for home production and caretaking responsibilities, which in Kosovo are typically disproportionately borne by women in the household.

\section{Job characteristics}

Previous research suggests the inclusion in the earnings function of the total working experience as a further measure of human capital and that using age as a proxy for this is unlikely to be acceptable when analysing gender wage gaps. However, whilst data limitations preclude the inclusion of total work experience, we can include a measure of the number of years with the current employer: that is the uncompleted tenure in the current job and the square of the uncompleted tenure. To ascertain the impact on earnings of employment in the informal sector a binary variable is included in the earning functions: the dummy equals 1 if the employee possessed an employment contract and 0 if no contract existed. To differentiate between working arrangements, a dummy variable is included, equal to 1 for full-time work and 0 for part-time. In the monthly earnings function the 
number of working hours per month are included in the model.

\section{Employer characteristics}

Within employer characteristics explanatory variables, a variable differentiating between public, private and NGO and international organisations is included, the reference category is the private sector. The following five dummy variables for occupations are included: managers, professionals, craft and related trade workers, elementary occupations and other occupations. Service and sales workers is set as the reference category. Seven dummy variables for industry sectors are included: agriculture, manufacturing, construction, public administration, education, health and other sectors, with trade as the benchmark category.

\section{DETERMINANTS OF THE GENDER PAY GAP}

Mincer's wage equation examines the determinants that affect wages, but while wages are observed for employed individuals, the wage cannot be observed for those that are not working i.e. the inactive and unemployed. As a consequence, using only the sample of employed individuals might produce biased estimates of the parameters in the Mincer's wage equation. This would be the case if employed individuals have higher wages than those who are out of the labour force, had they been employed. Indeed, this might be the reason why the latter are not employed in the first place. The Heckman selection model (Heckman 1976; 1979) checks for the presence of sample selection bias, whereby the model consists of two equations, the wage equation and the selection equation. In addition to education, age, and household characteristics that are included in the wage equation, the selection equation includes an additional variable depicting if a person resides in an urban or rural area. Both Rho in the Heckman equation estimated by maximum-likelihood approach, and the inverse Mills ratio in the equation estimated by the Heckman two-step approach, are insignificant for both samples of male and female employees. These results suggest that sample selection bias is not a significant issue in our data. Therefore, results from OLS regressions are presented below.

As can be noted from Mincer wage equation results shown in Table 2, ceteris paribus, on average women are paid, $6.1 \%$ less than men per hour. This contrasts with the findings above for the unadjusted gender pay gap where women were on average paid $6.5 \%$ higher than men. The adjusted gross monthly wage gap is estimated to be $13.9 \%$, compared to $12.2 \%$ of the unadjusted one. Next, the empirical findings from the hourly wage regression are discussed.

Surprisingly, married women received $12 \%$ higher wages per hour, while the marital status is not significant for men. Age is significant for men only, influencing positively the hourly wage. Women have a flat age-earnings profile suggesting that age is a poor proxy for women's labour market experience or that their previous employment is not valued. In line with expectations, education is an important predictor of gross hourly wages, with more educated individuals received a higher wage per hour. The returns to education are slightly higher for men. Compared to males with no education or primary or lower secondary completed only (the reference category), males with upper secondary education or post-secondary education received $14 \%$ higher hourly wages (compared to $12 \%$ for women), those with tertiary received $42 \%$ ( $40 \%$ for women) higher wages than the reference category and those with $\mathrm{PhD}$ received a $61 \%$ premium ( $53 \%$ for women). There is no support for the motherhood penalty proposition, since the variable indicating the presence of children under age of 15 in the household is not significant for women. Though this variable is significant and is positive for men suggesting that men living in households with children under the age of 15 were paid $3 \%$ more per hour compared to their counterparts with no children under the age of 15 in the household. The variable for the presence of elderly in the household is not significant in any of the earnings functions.

With regards to job characteristics, the findings reveal a positive association between hourly wages and tenure with the current employer: for every additional year with current employer hourly wage of men and women increased by $1 \%$. Compared to private sector employees those in the public sector and those working for NGOs or international organisations were paid more per hour. Although this applies to both genders, the difference with the private sector is larger for men. Surprisingly, ceteris paribus, the hourly wage for parttime workers was higher than that for those working full-time: women employed full-time received $23 \%$ lower wages per hour while men received $20 \%$ lower hourly wages than their part-time employed counterparts. However, part-time working is still relatively rare (only $9.3 \%$ of women and $9.5 \%$ of men have part-time jobs) in Kosovo and limited to certain occupations and sectors. There is a large wage penalty for working in the informal sector: $14 \%$ for women and $26 \%$ for men. This is consistent with the adjusted gender wage gap being smaller in the informal economy, once 
Table 2. Mincer wage regression results

\begin{tabular}{|c|c|c|c|c|c|c|c|c|c|c|c|c|c|}
\hline & & \multicolumn{4}{|c|}{$\begin{array}{c}\text { Log hourly gross hourly wages: } \\
\text { ALL }\end{array}$} & \multicolumn{4}{|c|}{$\begin{array}{l}\text { Log gross hourly wages: } \\
\text { WOMEN }\end{array}$} & \multicolumn{4}{|c|}{$\begin{array}{c}\text { Log gross hourly wages: } \\
\text { MEN }\end{array}$} \\
\hline & & Coeff. & $\begin{array}{l}\text { Std. } \\
\text { Err.a }\end{array}$ & $\mathrm{t}$ & & Coeff. & $\begin{array}{l}\text { Std. } \\
\text { Err.a }\end{array}$ & $\mathrm{t}$ & & Coeff. & $\begin{array}{l}\text { Std. } \\
\text { Err.a }\end{array}$ & $\mathrm{t}$ & \\
\hline \multicolumn{14}{|l|}{ Individual level characteristics } \\
\hline Gender $=$ women $=1$ (DV) & DV & -0.061 & 0.02 & -3.56 & $* * *$ & & & & & & & & \\
\hline Marital status, married=1 (DV) & DV & 0.06 & 0.02 & 2.47 & ** & 0.12 & 0.04 & 3.18 & $* * *$ & 0.01 & 0.03 & 0.30 & \\
\hline Age & & 0.01 & 0.00 & 1.60 & & 0.001 & 0.01 & 0.13 & & 0.01 & 0.01 & 1.92 & 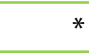 \\
\hline Age squared & & -0.0001 & 0.00 & -1.58 & & 0.000 & 0.00 & -0.21 & & 0.00 & 0.00 & -1.73 & * \\
\hline $\begin{array}{l}\text { Upper secondary education } \\
\text { and post-secondary voca- } \\
\text { tional (DV) }\end{array}$ & DV & 0.15 & 0.02 & 7.45 & $* * *$ & 0.12 & 0.05 & 2.4 & ** & 0.14 & 0.02 & 6.60 & *** \\
\hline Tertiary: BA and MA (DV) & DV & 0.43 & 0.03 & 15.14 & $* * *$ & 0.40 & 0.06 & 6.65 & $* * *$ & 0.42 & 0.03 & 12.55 & $* * *$ \\
\hline $\mathrm{PhD}(\mathrm{DV})$ & DV & 0.60 & 0.05 & 12.81 & $* * *$ & 0.53 & 0.08 & 7.02 & $* * *$ & 0.61 & 0.06 & 9.60 & $* * *$ \\
\hline $\begin{array}{l}\text { Living in a household with } \\
\text { children under age of } 15 \\
\text { years (DV) }\end{array}$ & DV & 0.01 & 0.02 & 0.92 & & -0.04 & 0.03 & -1.46 & & 0.03 & 0.02 & 1.90 & * \\
\hline $\begin{array}{l}\text { Living in a household with } \\
\text { elderly } 65 \text { and older }\end{array}$ & DV & 0.01 & 0.02 & 0.69 & & 0.03 & 0.03 & 1.08 & & 0.01 & 0.02 & 0.35 & \\
\hline \multicolumn{14}{|l|}{ Job characteristics } \\
\hline Tenure with current employer & & 0.01 & 0.00 & 2.85 & $* * *$ & 0.01 & 0.01 & 2.03 & $* *$ & 0.01 & 0.00 & 2.30 & ** \\
\hline $\begin{array}{l}\text { Tenure with current employer } \\
\text { squared }\end{array}$ & & -0.00001 & 0.00 & -0.14 & & 0.00 & 0.00 & -0.73 & & 0.00 & 0.00 & -0.02 & \\
\hline Public sector=1 (DV) & DV & 0.29 & 0.03 & 11.68 & $* * *$ & 0.19 & 0.05 & 3.66 & $* * *$ & 0.33 & 0.03 & 11.13 & $* * *$ \\
\hline $\begin{array}{l}\text { NGO or International organi- } \\
\text { sation=1 (DV) }\end{array}$ & DV & 0.20 & 0.06 & 3.44 & $* * *$ & 0.14 & 0.09 & 1.6 & & 0.22 & 0.08 & 2.70 & $* * *$ \\
\hline Full time employment=1 (DV) & DV & -0.21 & 0.03 & -6.14 & $* * *$ & -0.23 & 0.08 & -3.1 & $* * *$ & -0.20 & 0.04 & -5.22 & $* * *$ \\
\hline Formal employment=1 (DV) & DV & 0.24 & 0.02 & 12.67 & $* * *$ & 0.14 & 0.04 & 3.45 & $* * *$ & 0.26 & 0.02 & 12.19 & $* * *$ \\
\hline \multicolumn{14}{|l|}{ Occupations } \\
\hline Managers $=1(\mathrm{DV})$ & DV & 0.31 & 0.04 & 7.88 & $* * *$ & 0.39 & 0.08 & 4.92 & $* * *$ & 0.29 & 0.05 & 6.35 & $* * *$ \\
\hline Professionals=1 (DV) & DV & 0.30 & 0.03 & 9.20 & $* * *$ & 0.31 & 0.06 & 5.1 & $* * *$ & 0.31 & 0.04 & 7.58 & *** \\
\hline $\begin{array}{l}\text { Craft and Related Trades } \\
\text { Workers }=1 \text { (DV) }\end{array}$ & DV & 0.15 & 0.03 & 4.93 & $* * *$ & -0.12 & 0.08 & -1.55 & & 0.18 & 0.03 & 5.65 & *** \\
\hline $\begin{array}{l}\text { Elementary occupations }=1 \\
\text { (DV) }\end{array}$ & DV & 0.06 & 0.03 & 2.48 & $* *$ & 0.04 & 0.06 & 0.73 & & 0.07 & 0.03 & 2.50 & ** \\
\hline Other occupations=1 (DV) & DV & 0.14 & 0.02 & 6.21 & $* * *$ & 0.18 & 0.05 & 3.52 & $* * *$ & 0.14 & 0.03 & 5.15 & $* * *$ \\
\hline \multicolumn{14}{|l|}{ Sector dummies } \\
\hline Manufacturing (DV) & DV & 0.03 & 0.03 & 0.93 & & 0.07 & 0.07 & 1.04 & & 0.01 & 0.04 & 0.21 & \\
\hline Construction (DV) & DV & 0.20 & 0.03 & 6.15 & $* * *$ & 0.18 & 0.16 & 1.17 & & 0.17 & 0.04 & 4.67 & $* * *$ \\
\hline Agriculture (DV) & DV & -0.04 & 0.08 & -0.49 & & 0.32 & 0.23 & 1.39 & & -0.09 & 0.09 & -1.06 & \\
\hline $\begin{array}{l}\text { Public administration and } \\
\text { defence; compulsory social } \\
\text { security (DV) }\end{array}$ & DV & 0.02 & 0.04 & 0.56 & & 0.08 & 0.09 & 0.99 & & -0.02 & 0.04 & -0.59 & \\
\hline Education (DV) & DV & 0.05 & 0.04 & 1.26 & & 0.23 & 0.07 & 3.2 & $* * *$ & -0.06 & 0.05 & -1.25 & \\
\hline $\begin{array}{l}\text { Health and social work activi- } \\
\text { ties (DV) }\end{array}$ & DV & -0.03 & 0.04 & -0.77 & & 0.08 & 0.06 & 1.26 & & -0.10 & 0.05 & -2.07 & * \\
\hline Other service activities (DV) & DV & 0.02 & 0.03 & 0.56 & & 0.12 & 0.05 & 2.42 & $* *$ & -0.04 & 0.04 & -1.27 & \\
\hline Other sectors (DV) & DV & 0.10 & 0.03 & 3.57 & $* * *$ & 0.12 & 0.06 & 2 & $* *$ & 0.07 & 0.03 & 2.11 & * \\
\hline Number of observations & \multicolumn{5}{|r|}{4,447} & \multicolumn{4}{|r|}{1,134} & \multicolumn{4}{|r|}{3,313} \\
\hline $\mathrm{R} 2$ & \multicolumn{5}{|r|}{0.46} & \multicolumn{4}{|r|}{0.54} & \multicolumn{4}{|r|}{0.43} \\
\hline $\begin{array}{l}\text { Ramsey RESET test for linear- } \\
\text { ity: } F\end{array}$ & \multicolumn{5}{|c|}{259.65} & \multicolumn{4}{|r|}{33.39} & \multicolumn{4}{|r|}{212.88} \\
\hline
\end{tabular}

Notes: ${ }^{*} p<0.10 ;{ }^{* *} p<0.05,{ }^{* *} p<0.01 ; z$-statistics based on robust standard errors in parenthesis; for dummy variables (DV). a Robust standard errorS. 
adjusted for hours worked. Compared to service and sales workers, women employed as managers and professionals were paid higher wages per hour (39\% and $31 \%$ percent for women and $29 \%$ and $31 \%$ for men) while craft and related female workers were paid less, with no statistically significant difference with elementary occupations. For men, there are statistically significant differences across all occupations, with sales and service workers receiving the lowest wage per hour. Construction apart, there is little significant differences between the various sectors.

As expected, the gross monthly wages of those in full-time employment was higher than those employees working part-time, though the mark-up was higher for women (49\%) than for men (28\%). This may be due to female part-time workers either working shorter hours than their male counterparts or them facing a heavier penalty from part-time work. The former possibility is confirmed with the data, whereby women working part-time on average worked 107 hours per month compared to the 153 hours of men. In the gross monthly wage regression, the gains from working in the formal sector are larger for women-the mark-up for female employees is estimated at $17 \%$ compared to $13 \%$ for male employees. Interestingly, the findings suggest that higher wages are observed for those working in public administration and health sectors, whilst among men compared to the trade sector, those working in construction and manufacturing received higher wages, whilst those in education received lower wages.

The MCC Labour Force and Time Use Survey consisted of an extended questionnaire and time use survey, conducted with a sample of 8,604 individuals. We noted above that male employees had significantly longer working hours than their female counterparts. The Survey indicates that on average men spent more time commuting to work than women: on average men spent 55 minutes commuting compared to the 46 minutes of women, a statistically significant difference at $1 \%$. Joyce and Keiller (2018) argue that a gender commuting gap may be linked to the gender wage gap. Aiming to work closer to home because of their greater caring responsibilities, women consider working within a smaller locality than men, with a lower likelihood of finding a job that fully matches their skills. In addition, they conjecture that employers offer lower wages to women, knowing that they search in a smaller local labour market. An additional explanation is that mothers who work closer to home may also require/demand shorter and more flexible working arrangements which can lead to a further wage penalty (Joyce and Keiller 2018).
Employed women spent significantly more time on home production and other related chores. On average they spent 3 hours per day on home production such as preparing food, cleaning, etc. compared to the 1 hour spent by men. They also allocated 1.4 hours per day looking after children whilst male employees spent just 0.66 of per hour. In addition, employed women spent 0.75 of an hour-daily helping other household adult members compared to the 0.62 of an hour of men. These gender differences in unpaid home production and care work, according to Ferrant et al. (2014) are also directly linked to the size of gender wage gaps. In countries where women spend a large amount of time on unpaid care and there is a large gender gap in the time spent in unpaid work, the gender gap in hourly wages is also higher.

\subsection{Decomposition analysis}

The Blinder-Oaxaca decomposition (Blinder 1973; Oaxaca 1973) is a methodology commonly utilised in the study of differences in labour market outcomes by groups (sex, age groups etc.). The decomposition is based on separate Mincer earnings equations for men and women. A unique feature of the BO decompositions method is that it divides the wage differential between two groups into a part that is "explained" and "unexplained". The explained gap is the difference between men and women due to observed differences in explanatory variables/difference in endowments or labour market characteristics. On the other hand, the unexplained part is the difference attributable to the different wage equations of men and women, labelled as the difference in entitlements (returns) or the wage structure effect (Avlijaš et al. (2013). This means that the wage difference between men and women is due to different returns to the independent variables/differing coefficients plus the wage difference between men and women which is not captured by the independent variables/difference in intercepts or the shift parameters (Reimer and Schröder 2006). By 'taking away' the part of the unadjusted pay gap that is due to the differences in the labour market characteristics of women and men, the remaining part compares wages of men and women with the same observed labour market characteristics (such as education, work experience, etc.). This part of the gap, the unexplained part, is also called the adjusted pay gap, representing the "true" magnitude of the gender wage gap. The "unexplained" part is often used as a measure for discrimination, but it also subsumes the effects of group differences in unobserved predictors and ignores the 
possibility that the observed labour market characteristics may themselves be affected by discriminatory behaviour or the anticipation of such behaviour. ${ }^{3}$ However, the Blinder Oaxaca (BO) decomposition allows for an aggregate quantitative accounting of how much of the gender wage gap is explained by differences in relevant labour market skills, but it also indicates specific sources of the gap, for example, gender differences in either amounts of education or years of work experience or in their returns (Kunze 2018). The estimates from the earnings function summarised in the basic Blinder-Oaxaca decomposition are shown in Table $3^{4}$. Based on the decomposition output, the reported mean of the log of hourly wages is 0.633 for men and 0.702 for women, yielding a wage gap of 0.069 in favour of women. Next, the wage gap is decomposed into the explained part and the unexplained part. While the results indicate that, on average, employed women have a $6.9 \%$ higher hourly wage than employed men, given that the 'explained part' coefficient is negative, it implies that the differences in labour market characteristics between men and women cannot explain the observed gender hourly wage gap in Kosovo. Indeed, when including personal characteristics, the gap changes from a $6.9 \%$ gap favouring female employees to a $6.1 \%$ gap in favour of male employees. This estimate ccompares the wages of men and women with the same observed labour market characteristics (such as education, work experience, etc.) implying that wages of women are $6.1 \%$ lower than their male counterparts, with similar characteristics and this gap is due to differences in unmeasured characteristics or discriminatory behaviour.
It is important to emphasise that there are some challenges in interpreting the decompositions (Kunze 2018) due to the: possible correlation of the explanatory variables and the error term due to omitted variables; imperfect measurement of employees' characteristics when calculating the explained part in the decomposition in equation (e.g. work experience); and the possibility of an overstated explained part as it relates to productivity-related characteristics if discriminatory behaviour affects the values of those explanatory variables. Taken together these possibilities mean that the unexplained part, as measured by the residual, does not necessarily measure unjustified wage differences, i.e. the extent of discrimination, in the labour market.

With regards to the gross monthly gap, the results in Table 3 indicate that on average women earn 10.5\% less (the unadjusted gender pay gap) than their male counterparts. Again, the coefficient of the explained part is negative, indicating that the differences in labour market characteristics between men and women (e.g. education, tenure, job characteristics, etc.) does not explain the gender monthly wage gap. Indeed, when personal labour market characteristics are taken into account, the gap widens from $10.5 \%$ to $13.9 \%$ (the adjusted gender pay gap). This implies that once we correct for female employees having "better" characteristics than male employees, the gender monthly wage gap becomes larger. Thus, the adjusted monthly wage gap in Kosovo is higher than the unadjusted monthly wage gap, i.e. the differences in labour market characteristics again hide the true magnitude of the gender wage gap.

Table 3. Blinder-Oaxaca decomposition, main results

\begin{tabular}{|c|c|c|c|c|}
\hline Gross hourly wages & Coefficients & Robust st. errors 5 & $z$ & $\mathrm{P}>|\mathrm{z}|$ \\
\hline Men & 0.633 & 0.01 & 60.8 & 0.00 \\
\hline Women & 0.702 & 0.02 & 37.6 & 0.00 \\
\hline Difference & -0.069 & 0.02 & -3.2 & 0.00 \\
\hline Explained part & -0.129 & 0.02 & -7.6 & 0.00 \\
\hline Unexplained part & 0.061 & 0.02 & 3.6 & 0.00 \\
\hline \multicolumn{5}{|l|}{ Gross monthly wages } \\
\hline Men & 5.844 & 0.01 & 731.0 & 0.000 \\
\hline Women & 5.739 & 0.01 & 383.8 & 0.000 \\
\hline Difference & 0.105 & 0.02 & 6.2 & 0.000 \\
\hline Explained part & -0.035 & 0.01 & -3.2 & 0.002 \\
\hline Unexplained part & 0.139 & 0.01 & 11.8 & 0.000 \\
\hline
\end{tabular}

Source: MCC LFTUS 2017, authors' calculations 


\section{CONCLUSION: UNDERSTANDING THE GENDER PAY GAP IN KOSOVO}

Whilst Kosovo appears to be unique in having the reverse of the traditional gender gap in terms of average unadjusted hourly gross wages, the analysis above indicates that any comparison of male and female wages requires a careful analysis. When monthly unadjusted gender wage gaps are examined the longer working hours of males restores the norm finding of a male premium. Once the analysis is expanded further to include differences in productivity-related characteristics, employee preferences and job characteristics then a more familiar scenario of significant male wage premiums emerges in the Kosovar labour market. However, in comparison to Avlijaš et al. (2013) results for three other Western Balkan countries, Northern Macedonia, Montenegro and Serbia, the adjusted gender wage gap in Kosovo appears to be relatively small. The decomposition analysis shows that given their characteristics we would expect female employees in Kosovo to have, on average, significantly higher wages than males than that observed. Taking these results together we have shown that even in situations where women have higher unadjusted wages than men, they may be still be severely penalised in the labour market. However, a limitation of our decomposition analysis is that though this penalty is likely to arise from differences in unobserved characteristics, such as innate or socially programmed preferences or direct discrimination by employers, we are unable to unpick their relative importance.

The analysis of gender wage gaps reported above yields some detailed insights into the workings of a chronically depressed labour market. Both male and female employees in Kosovo received a significant wage penalty if working in the informal economy. Education premiums were large, even without taking into effect the impact of higher educational attainment on labour force participation. We found that the age-earning profile for female employees was flat, although there was a small return to tenure. Some of the findings cannot be easily explained. Surprisingly we found no evidence of a motherhood wage penalty, though the absence of a penalty may reflect data deficiencies identified above. We did find a premium for married females but not for married men. Equally surprising was the finding that both female and male part-time employees had significantly higher hourly wages than their full-time equivalents. There was no net effect of having elderly members in the household, suggesting that the effect on preferred working hours of potentially having child care available in house was offset by an increased demand for home production and caring activities. Overall, we found that female employees spent on average 5.15 hours a day on home production and caring activities, over twice the time spent by male employees. We did find evidence that these differences in the allocation of time contributed to the gender wage gap through women working significantly shorter hours and having shorter commutes to their work.

The interaction of a number of factors will determine the future behaviour of the gender wage gaps in Kosovo. The statistical curiosity of a negative unadjusted hourly gender wage gap is likely to disappear as the FLFP rises and the productivity-related characteristics of male and female employees converge. However, the likely growth of part-time working, particularly amongst mothers, a gender education gap favouring women and the eventual probable contraction of the informal economy, enforcement of overtime premia regulations and growth of home-working will each have an effect on the gender wage gaps in Kosovo, as will any changes in social attitudes and traditional family roles, the extent of nepotism and discriminatory employer behaviour.

\section{Endnotes}

1 The Mincer (Mincer 1974) earnings function relates the log of individual wages to gender, measures of the individual's human capital (education and work experience) and other labour market characteristics. See below for a discussion of the preferred specification in this study.

2 The BO decomposition does not allow an assessment of the impact of changes in economy-wide wage inequality, which will be of relevance in those countries, for example with increased returns to education. The impact of these changes can be captured through the Juhn-Murphy-Pierce decomposition (1991) allowing the individual-specific effect to vary over time. However, due to a lack of suitable data for Kosovo, this methodology cannot be employed.

3 A detailed explanation can be found in Avlijaš et al. (2013).

4 This large gap favouring women is likely to be due to the relatively small number of women who work in this sector, predominantly holding positions in administration.

5 The pooled option is used, which reports robust standard errors (Oaxaca uses suest to estimate the joint variance matrix for all coefficients when pooled is specifiedJann, 2008 pg. 17, 10th footnote). 


\section{REFERENCES}

Adda, J., Dustmann, C. and Stevens, K. 2017. The career cost of children. Journal of Political Economy 125(2): 293-337.

Arulampalam, W., Booth, A. and Bryan, M. 2007. Is there a glass ceiling over Europe? Exploring the gender pay gap across the wage distribution. ILR Review 60(2): 163-86.

Avlijaš, S., Ivanović, N., Vladisavljević, M. and Vujić, S. 2013. Gender pay gap in the Western Balkan Countries: Evidence from Serbia, Montenegro and Macedonia. FREN - Foundation for the Advancement of Economics: Belgrade, Serbia.

Blau, F. and Khan, L. 2016. The gender wage gap: Extent, trends and explanations. Journal of Economic Literature 55(3): 789-865.

Blinder, A. 1973 Wage Discrimination: Reduced form and structural estimates. Journal of Human Resources 8(4): 436-55.

Cha, Y. and Weeden, K. 2014 Overwork and the slow convergence in the gender gap in wages. American Sociological Review 79(3): 457-84.

Chowdbury, I., Johnson, H., Mannawa, A. and Perova, E. 2018. Why do Vietnamese women work in lower paid occupations? World Bank Policy Research Working Paper No. 8433.

Cukrowska-Torzewska, E. and Matysiak, A. 2018. The motherhood wage penalty: a meta-analysis. Vienna Institute of Demography Working Paper No. 08/2018.

Goldin, C. 2014. A grand gender convergence: its last chapter. American Economic Review 104(4): 1091-119.

Ferrant, G., Pesando, L.C. and Nowacka, K. 2014. Unpaid care work: The missing link in the analysis of gender gaps in labour outcomes. OECD Development Centre. https:// www.oecd.org/dev/development-gender/Unpaid_ care_work.pdf.

Frederisen, A. and Kato, T. 2018. Human capital and career success: evidence from a linked employer-employee data. Economic Journal 128(613): 1952-1982.

Gashi, A., Rizvanolli, A. and Adnett, N. 2019. Bucking the trend: female labour force participation in Kosovo. Croatian Economic Survey 21(2): 85-116.

Heckman, J. J. 1976. The common structure of statistical models of truncation, sample selection and limited dependent variables and a simple estimator for such models. Annals of Econometrics and Social Measurement 5: 475-492.

Heckman, J. J. 1979. Sample selection bias as a specification error. Econometrica 47: 153-161.

Institute of Statistics of Republic of Albania. 2018. Women and Men in Albania 2018. http://www.instat.gov.al/media/4764/burra-dhe-grate-ne-shqiperi-2018.pdf.

Joyce, R. and Keiller, A. 2018. The 'gender commuting gap' widens considerably in the first decade after childbirth. International Financial Institute: https://www.ifs.org.uk/ publications/13673.
Juhn, C. and McCue, K. 2016. Evolution of the marriage earnings gap for women. American Economic Review 106 (5): 252-56. http://dx.doi.org/10.1257/aer.p20161120.

Khitarishvili, T. 2019. Gender pay gaps in the Former Soviet Union: a review of the evidence. Journal of Economic Surveys 33(4): 1257-1284.

Khitarishvili, T.,Rodriguez-Chamussy, L. and Sinha, N. 2018. Occupational segregation and the declining gender wage gap: the case of Georgia. World Bank Policy Research Working Paper No. 8583.

Kleven, H., Landais, C., Posch, J., Steinhauser, A. and Zweimuller, J. 2019. Child penalties across countries: evidence and explanations. American Economic Review Papers and Proceedings 109: 122-6.

Kosovo Agency for Statistics (KAS). 2020. Labour force survey 2019. https://ask.rks-gov.net/media/5369/anketa-efuqis\%C3\%AB-pun\%C3\%ABtore-afp-2019.pdf.

Kosovo Agency of Statistics (KAS). 2012b. Kosovo population and housing census 2011 final results: main data". Prishtina. April. https://ask.rks-gov.net/media/2075/ final-results_eng.pdf.

Kosovo Democratic Institute. 2017. Employees who have (no) rights. http://kdi-kosova.org/wp-content/uploads/2017/11/Punetoret-qe-s-kane-te-drejta-ENGFINAL.pdf.

Kunze, A. 2018. The gender wage gap in developed countries. In the Oxford Handbook of Women and the Economy, edited by S. Averett, L., Argys and S. Hoffman. Oxford University Press. Oxford.

Leythienne, D. and Ronkowski, P. 2018. A decomposition of the unadjusted gender pay gap using Structure of Earnings Survey Data. https://ec.europa.eu/eurostat/ documents/3888793/8979317/KS-TC-18-003-EN-N. pdf/3a6c9295-5e66-4b79-b009-ea1604770676.

Mincer, J. 1974. Schooling, experience and earnings Columbia University Press, New York.

Oaxaca, R. 1973. Male-female wage differentials in urban labor markets. International Labour Review 14(3): 693.709.

OECD. 2020. OECD Data, Paris. https://data.oecd.org/earnwage/gender-wage-gap.htm.

Pastore, F., Sattar, S., and Tiongson, E.2013. Gender differences in earnings and labour supply in early career: evidence from Kosovo's school-to-work transition survey. IZA Discussion Paper No. 7461. http://ftp.iza.org/ dp7461.pdf.

Petrongolo, B. and Ronchi, M. 2020. Gender gaps and the structure of local labor markets, IZA Discussion Paper No. 13143.

Redmond, P. and McGuinness, S. 2017. The Gender wage gap in Europe: job preferences, gender convergence and distributional effects. IZA Discussion Paper No. 10933.

Reimer, D. and Schröder, J. 2006. Tracing the gender wage gap: Income differences between male and female university graduates in Germany." Zeitschrift für 
Arbeitsmarktforschung - Journal for Labour Market Research, Institut für Arbeitsmarkt- und Berufsforschung (IAB), Nürnberg [Institute for Employment Research, Nuremberg, Germany], Vol. 39(2), 235-253.

Riinvest Institute. 2017. Lack of Job Security: Women in the Private Sector. https://www.riinvestinstitute.org/En/riinvest-story/228/lack-ofjob-security-women-in-the-private-sector/.

Salman, D., Said, M. and Monastiriotis, V. 2019. Feminization of occupations and its effect on gender wage gap in South Mediterranean Countries. FEMISE Research Paper No. 43.08.

Stotsky, J., Shibuya, S., Kolovich, L., and Kebhaj, S. 2016. Trends in gender equality and women's advancement. IMF Working Paper No. 16/21. https://www.imf.org/external/pubs/ft/wp/2016/wp1621.pdf.
Weeden, K., Cha, Y. and Bucca M. 2016. Long work hours, part-time work and trends in the gender pay gap, the motherhood wage penalty and the fatherhood wage premium. Journal of the Social Sciences 2(4): 71-102.

Weichselbaumer, D. and Winter-Ebmer, R. 2005. A metaanalysis of the international gender wage gap. Journal of Economic Surveys 19(3): 479-511.

World Economic Forum. 2019. Global gender gap 2020, Geneva: World Economic Forum.

Yahmed, S. 2016. Formal but less equal: gender wage gaps in formal and informal jobs in Brazil. ZEW Discussion Paper No. 16-085. 